\title{
Estimates of planktonic larval mortality using the marine gastropods Crepidula fornicata and C. plana
}

\author{
Jan A. Pechenik ${ }^{1, *}$, Stephen H. Levine ${ }^{2}$ \\ ${ }^{1}$ Department of Biology, Tufts University, Medford, Massachusetts 02155, USA \\ ${ }^{2}$ Department of Civil and Environmental Engineering, Tufts University, Medford, Massachusetts 02155, USA
}

\begin{abstract}
Estimates of planktonic larval mortality rates have varied widely over the past $50 \mathrm{yr}$, from about $0 \% \mathrm{~d}^{-1}$ to $80 \% \mathrm{~min}^{-1}$. Convincing estimates from field sampling programs have proved difficult to obtain. This study considered the impact of predation pressure on larval growth rates for 2 species of the gastropod genus Crepidula whose larvae grow linearly over time. We reasoned that slow-growing larvae should be more vulnerable to predators than fast-growing larvae, so that in the face of substantial predation pressure mean larval growth rates should increase over time, with larger individuals growing on average more rapidly than smaller individuals as the more vulnerable slower growers are preferentially culled from the population. Larvae of C. fornicata and C. plana were collected from the plankton and reared individually in the laboratory under controlled conditions of temperature and food supply; larvae that were large when captured had significantly higher mean growth rates, on average, than those that were small when captured. A computer simulation confirmed that such results are consistent with substantial rates of predation on slow-growing individuals.
\end{abstract}

KEY WORDS: Crepidula spp. $\cdot$ Larvae $\cdot$ Larval mortality

Because of the obvious technical problems of following larvae in the plankton, larval mortality is the most difficult life history variable to measure.

$$
\text { A. Hines (1986), p. } 513
$$

\section{INTRODUCTION}

Most benthic marine invertebrates in most taxa have dispersive larvae in their life histories; such groups include sponges, cnidarians, turbellarian flatworms, polychaete annelids, gastropod and bivalved molluscs, crustaceans, echinoderms, and urochordates. The females of such species have high fecundities, typically releasing 1 million to 100 million eggs per spawning (Thorson 1950). As noted by Thorson (1950), if adult populations are stable over long periods, high fecundities must indicate high mortality, and the higher the fecundity the greater that mortality must be. For external fertilizers, some fraction of this loss might be due to fertilization failure (Pennington 1985, Levitan et al. 1992, Yund \& McCartney 1994, reviewed by Morgan 1995, Atkinson \& Yund 1996, but see Marshall 2002). But for eggs that do become fertilized, most mortality is generally assumed to occur in the plankton (reviewed by Thorson 1950, Young \& Chia 1987, Rumrill 1990, Morgan 1995). Average mortality rates for planktonic larvae have been estimated at $23 \% \mathrm{~d}^{-1}(\mathrm{SD}=23 \%$, $\mathrm{n}=30$ studies, Morgan 1995).

This idea of high planktonic mortality for the larvae of benthic marine invertebrates has been controversial for some time. Some authors have suggested that most developmental mortality occurs not in the plankton but at the time of substrate exploration in preparation for metamorphosis (reviewed by Pechenik 1979). Pechenik (1979) argued that 'mixed' life-history patterns (i.e. patterns in which embryos emerge as long-lived planktonic larvae after developing for a time within egg masses, egg capsules, or brood chambers) make 
the most adaptive sense if larval mortality is less in the plankton than it would be for pre-swimming, benthic embryos; brooding and encapsulation in mixed life histories might serve primarily to protect developmental stages until they can actively swim into the relatively safer plankton. The benthos is essentially a 2-dimensional environment, with predators often densely packed, while the plankton offers a third dimension in which to 'escape'. Predation on larvae by benthic suspension feeders can be substantial (reviewed in Pechenik et al. 2004).

Mortality can also be extremely high in the first 24 to $48 \mathrm{~h}$ after metamorphosis (Walters \& Wethey 1996, Doherty et al. 2004; reviewed by Gosselin \& Qian 1997 , Hunt \& Schiebling 1997), so that a great deal of developmental mortality must also occur after the planktonic phase has ended (e.g. Thorson 1966, Stoner 1990, Doherty et al. 2004).

So how unsafe is it for larvae to be in the plankton? Convincing field data on planktonic mortality rates for larvae have been notoriously difficult to obtain. Most data reported in the literature relied on sampling programs that required many untested, untestable, or suspect assumptions (reviewed by Strathmann 1985, Hines 1986, Rumrill 1990). Herein we report a new approach to the problem, a combination of laboratory, field, and modeling approaches that exploit the constant shell growth rates (Pechenik 1978, 1980, Lima \& Pechenik 1985, Klinzing \& Pechenik 2000) exhibited by larvae of the marine gastropods Crepidula fornicata and C. plana.

If mortality rates are high for planktonic larvae in the field, slower-growing larvae should suffer greater mortality than faster-growing larvae, simply because they are likely to take longer to become competent to metamorphose (e.g. Pechenik \& Lima 1984, Zimmerman \& Pechenik 1991, Bergenius et al. 2002). Thus, high larval mortality should reveal itself through an effect on mean larval growth rate: selection against morevulnerable, slower-growing individuals should increase the mean growth rate of the planktonic population as it ages, through the preferential survival of fastergrowing individuals over time. Conversely, if planktonic predation is negligible we would expect the average growth rate of larvae in a cohort to remain constant over time, since there will be no selection against slower-growing individuals.

This study was undertaken using larvae belonging to the gastropod genus Crepidula (C. fornicata and, to a lesser extent, C. plana), species with abundant and easily recognizable larvae (Thiriot-Quivreux \& Scheltema 1982, Pechenik 1986) that, in terms of both shell length and biomass, grow at a constant rate under a variety of temperature and food conditions in the laboratory (Pechenik 1978, 1980, 1984, Lima \& Pechenik
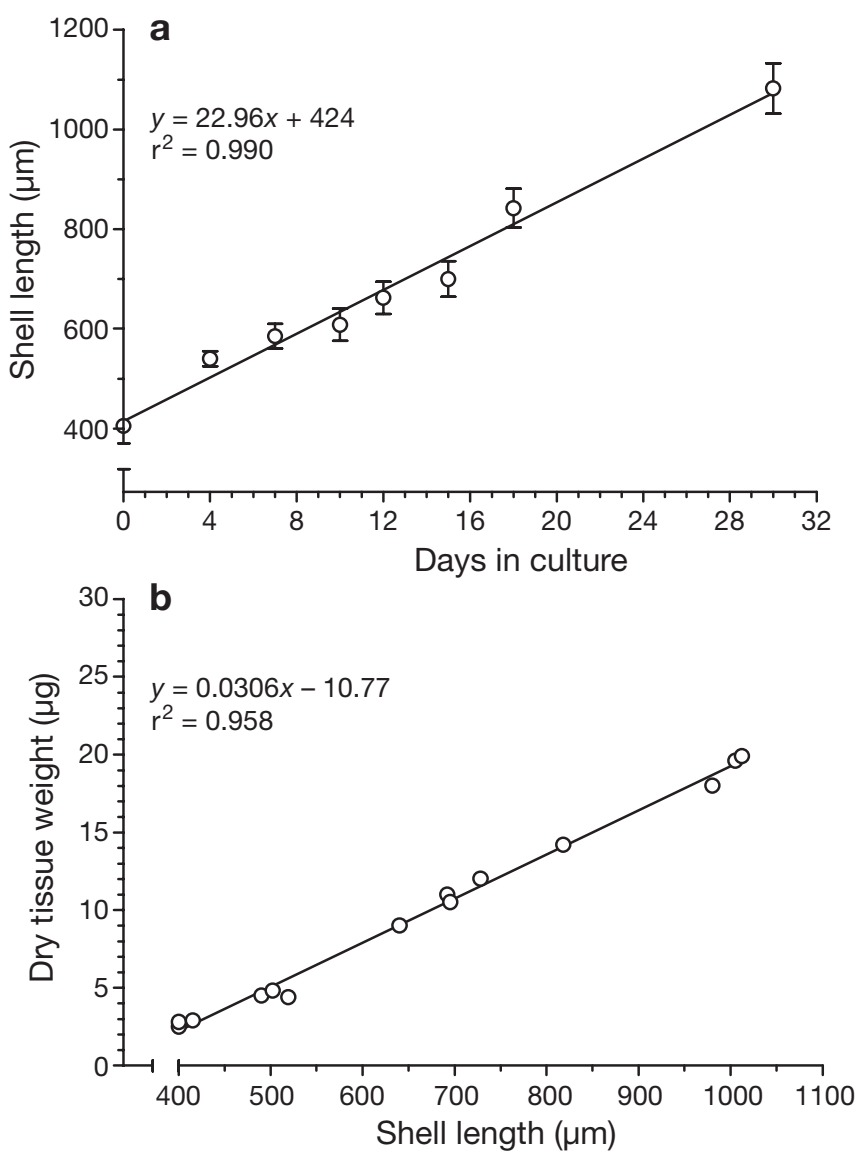

Fig. 1. Crepidula fornicata. (a) Relationship between larval shell length and larval age at $20^{\circ} \mathrm{C}_{i}$ each data point represents mean ( $\pm 1 \mathrm{SD}$ ) of 15 to 22 measurements (data from Pechenik 1978). (b) Relationship between larval shell length and dry tissue weight (ash-free dry weight); each data point represents single measurement of grouped larvae (2 to 10 individuals group ${ }^{-1}$ ). Tissue weight was determined by reweighing samples after combustion for $6 \mathrm{~h}$ at $525^{\circ} \mathrm{C}$ (data from Pechenik 1978, 1980)

1985, Klinzing \& Pechenik 2000) (Fig. 1). The broad sense heritability estimate for larval growth rate of $C$. fornicata is 0.35 (Hilbish et al. 1999), so that, to a large extent, growth rate differences among larvae reflect inherent physiological differences. Because individual growth rates are constant for larvae of both species, growth rates can be compared regardless of initial larval size. Our basic approach considers that, on average, small larvae will be younger than large larvae, and that large larvae should therefore, on average, have been exposed to predators in the plankton for more time, allowing more time for selection against slower-growing individuals. The pool of large larvae should therefore contain fewer slower-growing individuals than the pool of small larvae, increasing the mean growth rate for large larvae. We therefore col- 
lected larvae of Crepidula spp. in the field, sorted them into 2 size groups, and then reared the larvae individually in the laboratory under controlled conditions of temperature and food supply for several days to determine their growth rates. A failure to find significant differences in the mean growth rates of large and small larvae would support recent indications (e.g. Johnson \& Shanks 2003) that planktonic mortality rates can be negligible.

If we were able to follow a single cohort of larvae over time, interpreting the growth rate data would be straightforward: substantially higher mean growth rates of large versus small larvae would indicate substantial planktonic predation. However, female Crepidula fornicata and C. plana in New England release larvae into the plankton continuously between late spring and early fall (Costello \& Henley 1971), so that samples taken in the middle of the season will include a random mixture of larval cohorts. Many of the largest individuals captured will be slow-growing and old, while other comparably sized large individuals will be fast-growing and much younger. Similarly, some of the smallest individuals captured will be small only because of their recent release into the plankton, while others will be comparably small because they have been growing only slowly. To help interpret the growth rate data obtained in the laboratory from fieldcollected larvae and to better understand the potential impact of predation on larval growth rates in the plankton, we therefore developed a computer model in which we could manipulate all of the following: larval growth rate, variation in larval growth rate, variation in planktonic mortality rate, the extent to which larval mortality rates are size-dependent, the number of larvae hatching daily, and the duration of the study.

\section{MATERIALS AND METHODS}

Collecting larvae from the field. Plankton were sampled in 5 min tows from a dock in Narragansett Bay, Rhode Island, USA, using nets with $150 \mu \mathrm{m}$ Nitex mesh. The larvae of Crepidula fornicata are at least $400 \mu \mathrm{m}$ in shell length when released from the parent (Pechenik 1984, Pechenik et al. 1996a,b,c), and those of C. plana are at least $300 \mu \mathrm{m}$ in shell length (Lima \& Pechenik 1985). Plankton samples were placed in a cooler and transported to Tufts University, where they were examined using a dissecting microscope at $8 \times_{i}$ larvae of Crepidula spp. were removed and transferred to individual tissue culture wells containing $10 \mathrm{ml}$ of filtered $(0.45 \mu \mathrm{m})$ seawater. The larvae of $C$. fornicata (and probably those of C. plana) stop growing as soon as their food supply is removed (Pechenik et al. 1996a,b). The following day, after $24 \mathrm{~h}$ of acclima- tion to laboratory temperature $\left(\sim 23^{\circ} \mathrm{C}\right)$, each larva was measured nondestructively (Pechenik 1984, Pechenik \& Lima 1984, Pechenik et al. 1996b) to the nearest $0.2 \mu \mathrm{m}$ at a magnification of $50 \times$ and returned to its container; the filtered seawater was then replaced with $40 \mathrm{ml}$ of phytoplankton suspension (Isochyrisis galbana, Clone T-ISO) at a concentration of approximately $2 \times$ $10^{5}$ cells ml ${ }^{-1}$ (Pechenik 1984, Lima \& Pechenik 1985, Pechenik et al. 1996a,b,c). Larvae with shell lengths up to $650 \mu \mathrm{m}$ were classified as 'small', while larvae with shell lengths of 700 to $850 \mu \mathrm{m}$ were classified as 'large'. Larvae with shell lengths between 650 and $700 \mu \mathrm{m}$ were excluded from the study to avoid overlap between size categories. Larvae larger than about $850 \mu \mathrm{m}$ were also excluded from the study, to avoid working with larvae that might be, or might become, competent to metamorphose during the study (Pechenik \& Heyman 1987, Pechenik \& Gee 1993).

Larvae were transferred to a new food suspension each day for $3 \mathrm{~d}$, and then each was remeasured. All larvae were then reared for an additional 7 to $10 \mathrm{~d}$ until their metamorphosis could be triggered by excess potassium in seawater (Pechenik \& Heyman 1987, Pechenik \& Gee 1993, Pechenik et al. 2002). Juveniles were reared for 3 to $5 \mathrm{~d}$ until their identity as Crepidula fornicata or C. plana could be confirmed.

Plankton were sampled on 3 occasions for this study: 2 tows were made in 1994 (June 18 and July 8) and 1 tow was made on June 22, 1997. Growth rates of large and small larvae were compared by unpaired $t$-tests, using GraphPad Prism 3.03 software.

Computer simulation model. In order to explore the potential effects of predation on the growth rates of surviving larvae in the field, we developed an individual-based stochastic simulation model (Namatame et al. 2002, Chowhury et al. 2004, Evans \& Kelley 2004, Pie et al. 2004; see also http://www.webct.pdx.edu/ public/sysc610abs/). The simulation was implemented in Excel using Visual Basic for Applications (VBA).

The model was not developed with the intention of making field predictions about larval growth rates or the intensity of predation upon larvae; rather, the model served to indicate the soundness of our prediction that predation in the field would cause differences in the mean growth rates of large and small larvae, even when those larvae represented members of many different cohorts.

Individual-based models are characterized by computation that is decentralized rather than centralized. Each individual, in this case a gastropod larva, has parameters uniquely associated with it, instead of there being parameters representing the aggregate properties of the entire population. The mean population behavior then 'emerges' during the simulation from the aggregate experiences of individual larvae. 
Individual-based stochastic simulations are essentially simulated experiments, with each run of a simulation a replication; the data can then be handled exactly as for data collected from living organisms.

In our simulation, each Crepidula spp. larva was assigned a hatching size and growth rate, each chosen from normal probability distributions for which we specified the means and standard deviations. Based upon numerous laboratory studies (e.g. Pechenik 1984, Pechenik et al. 1996c), mean hatching size ( \pm 1 SD) was set at $432 \pm 20.3 \mu \mathrm{m}$ and mean larval growth rate was set at $60.3 \pm 15 \mu \mathrm{m} \mathrm{d}^{-1}$. We were also able to select the daily mortality rate for each run of the model, and to control whether mortality was size-dependent (increasing or decreasing with larval size) or sizeindifferent. When mortality was size-dependent, it could be set to either change gradually with growth or to change immediately once larvae reached a specified size threshold $(650 \mu \mathrm{m})$. Many of our simulations were run using a mortality rate of $0.23 \mathrm{~d}^{-1}$, which is about the average of mortality rates estimated for larvae in the literature (Rumrill 1990, Morgan 1995).

The simulation determines (for each individual on a daily basis) whether that individual escapes predation and, if so, whether it then metamorphoses. These determinations were again stochastic, with the probabilities in both cases being functions of an individual's size. Based on previous laboratory studies (Pechenik 1984, Pechenik \& Heyman 1987, Pechenik \& Gee 1993, Pechenik et al. 1996c), we had $50 \%$ of the larvae metamorphose at a shell length of $850 \mu \mathrm{m}$; the probability of metamorphosing on a given day then increased so that all surviving larvae would have metamorphosed by the time they reached a shell length of $1100 \mu \mathrm{m}$. The determination of whether or not a larva metamorphosed on any given day involved drawing a random number from a uniform distribution with a range from 0 to 1 , and comparing that number to the computed probability of metamorphosis. Thus, if an individual larva's probability of metamorphosing on a given day was 0.37, a random number between 0.0 and 0.37 would be interpreted as the individual undergoing metamorphosis, whereas a random number between 0.37 and 1.0 would be interpreted as the individual remaining a larva.

We further specified the number of days included in the simulation and the number of hatchings $d^{-1}$ for each run of the model. Most simulations lasted for $30 \mathrm{~d}$ with 200 larvae hatching each day; thus, 6000 larvae were generally tracked for each simulation. At hatching, larvae always were given a mean shell length of 432.8 (SD = 20.3) $\mu \mathrm{m}$ (Pechenik et al. 1996a). Each 'experiment' consisted of 10 runs with parameter values chosen from identical distributions. We classified those larvae alive at the end of each run as either small or large, using the same criteria that were used for the laboratory studies. For all the simulations reported, small larvae are those individuals with shell lengths up to $600 \mu \mathrm{m}$, while large larvae had shell lengths of 650 to $825 \mu \mathrm{m}$.

At the end of each run, the program calculated the number of larvae eaten, the number remaining alive, and the average growth rates of larvae surviving in the 2 different size categories.

The simulation is available for downloading at (http://ase.tufts.edu/BIOLOGY/faculty/pechenik/lab LarvalModel.asp).

Data analysis. Mean growth rates in laboratory studies were analyzed by unpaired $t$-tests, after checking for homogeneity of variance, using GraphPad Prism 3.03 software. Synthetic 'data' obtained from computer simulations were statistically treated in the same way that we treated our laboratory data since, for each experiment, the simulation provided data on mean growth rates and standard deviations for larvae in each of the 2 size categories. For laboratory data, variances were compared using Levene's test for equality of variances (Levene 1960) using SAS. For simulation data, where sample sizes were much greater, variances were compared using a standard F-test for homogeneity of variance.

\section{RESULTS}

\section{Field and laboratory data}

In all 3 samples in both years, larvae of Crepidula fornicata that were large when collected from the plankton (shell lengths $\geq 700 \mu \mathrm{m}$ ) grew significantly faster in the laboratory (C. fornicata: June 18, 1994, $t=$ 11.91, df = 124, $\mathrm{p}<0.0001$; July 8, 1994, $t=3.93, \mathrm{df}=$ 82, $\mathrm{p}=0.0002 ; 1997: t=5.09, \mathrm{df}=109, \mathrm{p}<0.0001$ ) than those that were small when collected from the same samples (Fig. 2). Although maximum growth rates were similar for larvae in the 2 size groups, the slowest growth rates recorded for small larvae were underrepresented among larger larvae (Fig. 3). Growth rate variances were significantly greater for small larvae than for large larvae of $C$. fornicata only in the July 8, 1994 sample (Levene's test: $F=6.25$, df $=1,82, \mathrm{p}=$ 0.0144).

The same trends were seen for larvae of Crepidula plana, based on the one sample that had sufficient numbers of larvae of this species for analysis; as with larvae of C. fornicata, larger larvae of C. plana grew on average faster than smaller larvae $(t=2.30, \mathrm{df}=33, \mathrm{p}=$ 0.028) (Fig. 4, bars on left), and the difference in growth rates was again largely due to the absence of very slow-growing individuals among large larvae 


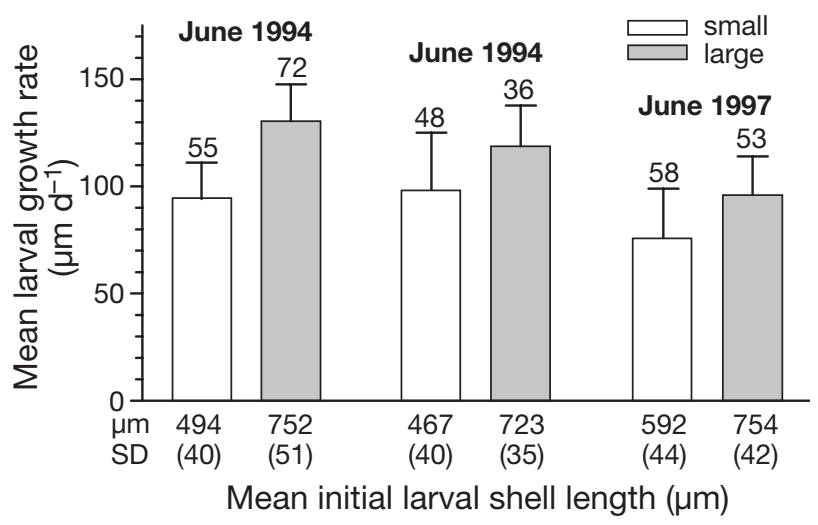

Fig. 2. Crepidula fornicata. Growth rates of small $(<650 \mu \mathrm{m})$ and large $(>700 \mu \mathrm{m})$ larvae isolated from plankton samples in Narragansett Bay on 3 different dates and then reared in the laboratory for $4 \mathrm{~d}$. Each bar represents mean (+1 SD) growth rate of 36 to 72 individuals (indicated above each bar). Numbers below $x$-axis indicate initial mean $(+\mathrm{SD})$ size of larvae in the different size categories

(Fig. 4, data points on right). Growth rate variances did not differ significantly for large and small larvae of $C$. plana in this July 1994 sample (Levene's test: $F=1.96$, df $=1,33, p=0.17$ ).

\section{Computer simulation results}

The results of $5 \mathrm{~d}$ simulations were substantially different from those of longer simulations, whether mortality rates were held constant (Fig. 5a), allowed to decline with increasing larval size (Fig. 5b), or allowed to increase with increasing larval size (Fig. 5c). The magnitudes of the mean differences in growth rates

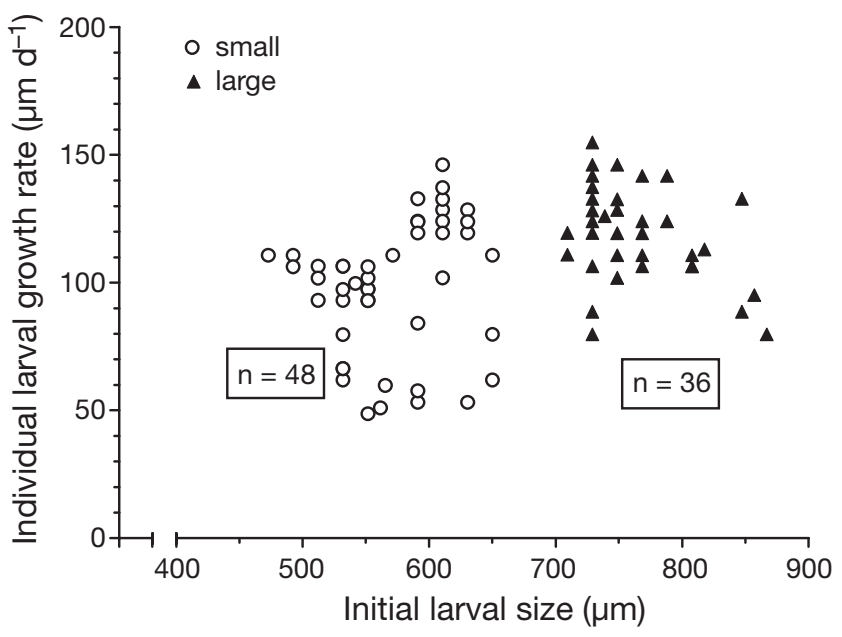

Fig. 3. Crepidula fornicata. Distribution of individual growth rates as a function of initial shell length for larvae obtained from plankton tows in Narragansett Bay on July 8, 1994

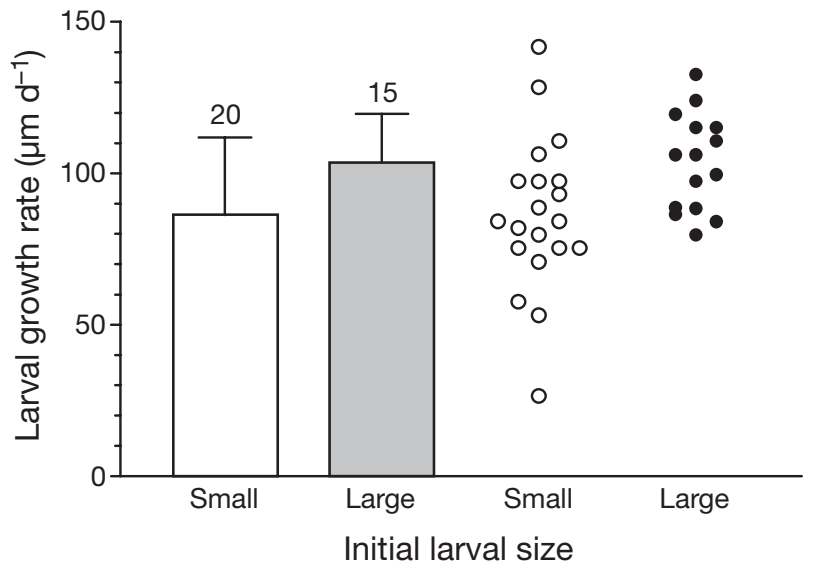

Fig. 4. Crepidula plana. Growth rates of large and small (see Fig. 2) larvae collected from plankton in July 1994 and then reared for $4 \mathrm{~d}$ in the laboratory. Same data are presented in 2 different ways to show both mean $(+\mathrm{SD})$ growth rates (bars) and distribution of individual growth rates (on right). Numbers above bars indicate number of larvae in each size category

between large and small larvae were greater than those in longer simulations (Fig. 5). All subsequent simulations were run for $30 \mathrm{~d}$. Of particular interest, the average growth rates of large and small larvae surviving at the end of the $30 \mathrm{~d}$ simulations differed significantly whether mortality rates were held constant or whether they were allowed to either increase or decrease with increasing larval size (e.g. Fig. 5a,b), either suddenly or gradually. Mean larval growth rates were not affected by the numbers of larvae hatching each day (Fig. 6). Subsequent simulations were run with 200 larvae hatching daily; this number was generally sufficient to produce at least 20 surviving larvae in each of the 2 size categories at the end of each simulation. Average growth rates for surviving large and small larvae also differed significantly at the end of the $5 \mathrm{~d}$ simulations (for the data shown in Fig. 5a, for example, $t=7.29$, df $=416, \mathrm{p}<0.0001)$.

A sample result for 1 run of the $30 \mathrm{~d}$ simulation is shown in Fig. 7a. In this run, more than $80 \%$ of larvae were eaten by predators during the simulation, with approximately 300 small larvae and 100 large larvae surviving at the end of the $30 \mathrm{~d}$ period. Other survivors either metamorphosed within those $30 \mathrm{~d}$ or were between 601 and $650 \mu \mathrm{m}$ in shell length and therefore excluded from both size categories. Final mean larval growth rates were not fixed by the parameters set but rather varied among runs for any given set of parameters (Fig. 7b).

The magnitude of the differences in mean growth rates for small and large larvae increased with increasing daily mortality rate (Fig. 8). No significant differences in mean growth rates were found when daily 

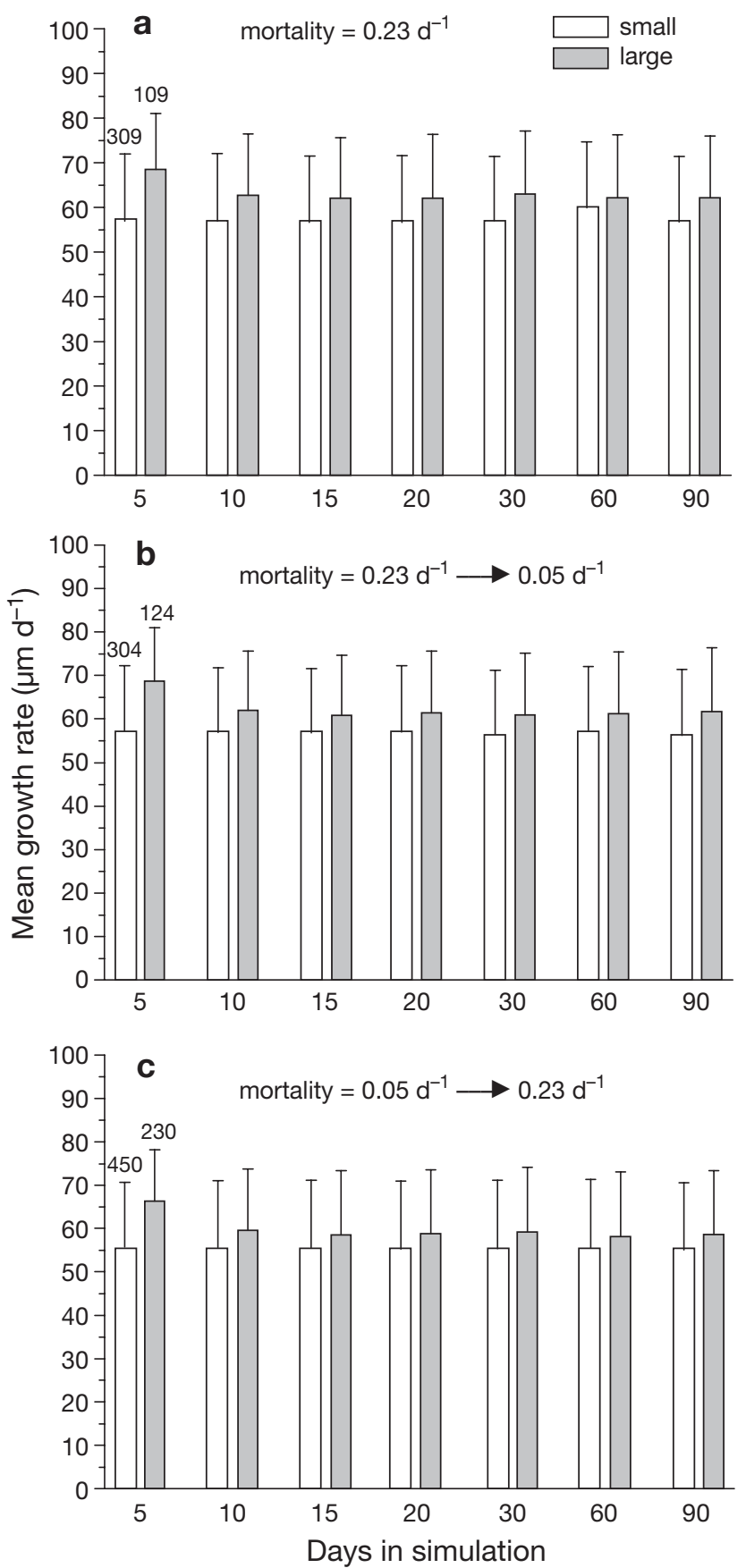

Fig. 5. Crepidula spp. Computer model. Effects of simulation duration on computer model output with (a) larval mortality constant at $0.23^{-1}$, (b) mortality rate declining suddenly during development from $0.23 \mathrm{~d}^{-1}$ for larvae $<650 \mu \mathrm{m}$ to $0.05 \mathrm{~d}^{-1}$ for larvae $\geq 650 \mu \mathrm{m}$, and (c) mortality rate increasing suddenly during development from $0.05 \mathrm{~d}^{-1}$ for larvae $<650 \mu \mathrm{m}$ to $0.23 \mathrm{~d}^{-1}$ for larvae $\geq 650 \mu \mathrm{m}$. Each experiment was run for the number of days shown on $x$-axes. Numbers above bars indicate number of larvae typically remaining in the 2 size categories at end of each $30 \mathrm{~d}$ simulation; error bars $=1 \mathrm{SD}$ above mean. Mean initial larval growth rate was $60.3 \pm 15 \mu \mathrm{m} \mathrm{d}^{-1}$, with 200 larvae hatching every day for 30 d (6000 larvae followed in total). Larvae with shell lengths between 600 and $650 \mu \mathrm{m}$ are not included in these data

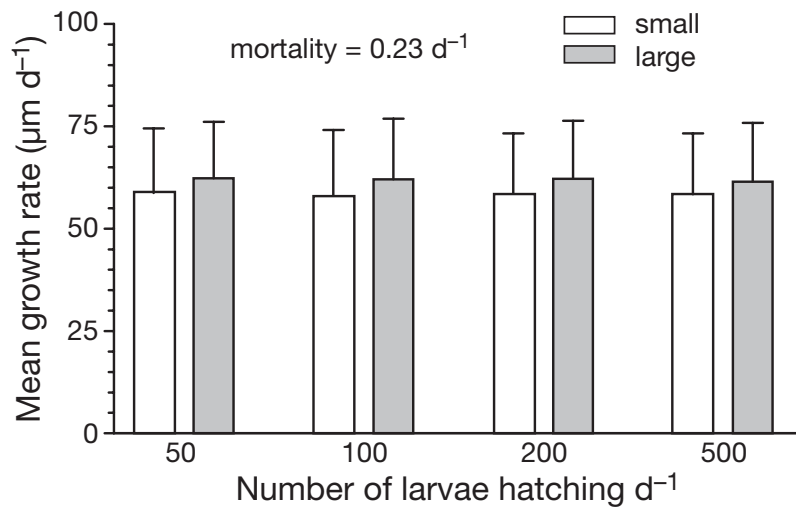

Fig. 6. Crepidula spp. Computer model. Influence of hatching rate on mean growth $(+1 \mathrm{SD})$ of larvae in 2 size categories (small $=<600 \mu \mathrm{m}$, large $=>650 \mu \mathrm{m})$. Numbers above bars indicate number of larvae in each category. Data generated by individual-based computer model with constant mortality of $0.23 \mathrm{~d}^{-1}$ and initial mean shell growth rate $( \pm \mathrm{SD})$ of $60.3 \pm$ $15 \mu \mathrm{m} \mathrm{d}^{-1}$. Data were recorded after $30 \mathrm{~d}$

mortality rate was zero, even with large numbers of larvae in each size category (Fig. 8a); this was expected, since there was nothing for selection to act on. However, with 200 larvae hatching $\mathrm{d}^{-1}$, differences in mean growth rates for larvae in the different size categories were significant $(t=2.65, \mathrm{df}=1055, \mathrm{p}=0.008)$ in the presence of larval mortality even at larval mortality rates of only $0.05 \mathrm{~d}^{-1}$ (Fig. 8a). This largely reflects the high degrees of freedom associated with these data $\left(\mathrm{df}=1055\right.$ when mortality $\left.=0.05 \mathrm{~d}^{-1}\right)$ : with only 50 larvae hatching $\mathrm{d}^{-1}$, differences in mean larval growth rates were not statistically significant until mortality was at least $0.4 \mathrm{~d}^{-1}$ (Fig. 8b). Despite the large sample sizes generated by the simulation, growth rate variances were generally not significantly different for large and small larvae (typical result from a $30 \mathrm{~d}$ simulation: $F=1.20, \mathrm{df}=308,181, \mathrm{p}=0.09$ ).

The above results were all obtained with daily larval growth rates of $60.3 \pm 15 \mu \mathrm{m} \mathrm{d}^{-1}$. The magnitude of the differences in mean growth rates for large and small larvae was even greater when variation about the simulated mean larval growth rates was increased (Fig. 9). The model also produced significant differences in the mean growth rates of large and small larvae regardless of initial larval growth rates (with SD allowed to increase in proportion to the increase in mean growth rate) (Fig. 10).

\section{DISCUSSION}

Our field and laboratory results for larvae of Crepidula fornicata and C. plana are consistent with the hypothesis of substantial rates of planktonic mortality for these 2 species, and selection in the field against 


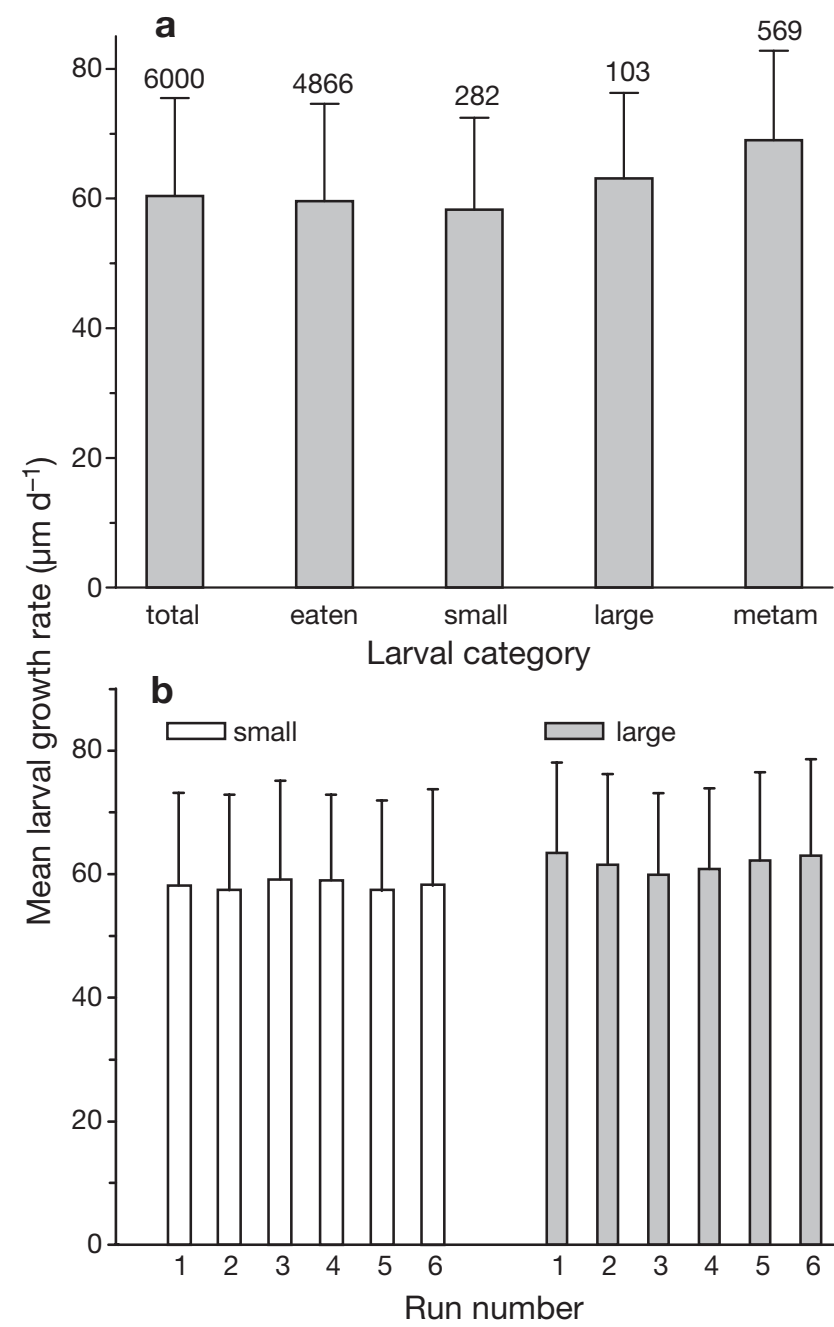

Fig. 7. Crepidula spp. Computer model. (a) Typical output from one run of individual-based computer simulation; each bar represents mean of 103 to 6000 individuals (indicated by number above each bar); 'large' and 'small' represent individuals found at end of $30 \mathrm{~d}$ simulation in 2 size categories, with 200 larvae hatching daily; mortality was constant at $0.23 \mathrm{~d}^{-1}$, and mean $( \pm \mathrm{SD})$ initial larvae growth rate was $60.3 \pm 15 \mu \mathrm{m}$ $\mathrm{d}^{-1}$; larvae with shell lengths between 600 and $650 \mu \mathrm{m}$ are not included in either 'small' or 'large' size categories. (b) Variability in model output among experiments; each bar represents mean (+1 SD) growth rate from 10 runs of the model

slower-growing individuals. For both species, larvae that were large (700 to $850 \mu \mathrm{m})$ when collected in the plankton had significantly higher mean growth rates $(p<0.05)$ in the laboratory than larvae that were smaller at the time of collection, and for both species, the differences largely reflected fewer slower-growing individuals in the samples of large larvae (Figs. $3 \& 4$ ). Even the largest larvae we worked with were below the size at which individuals of this species become competent to metamorphose, so that in the field they should not yet have been exploring benthic substrata

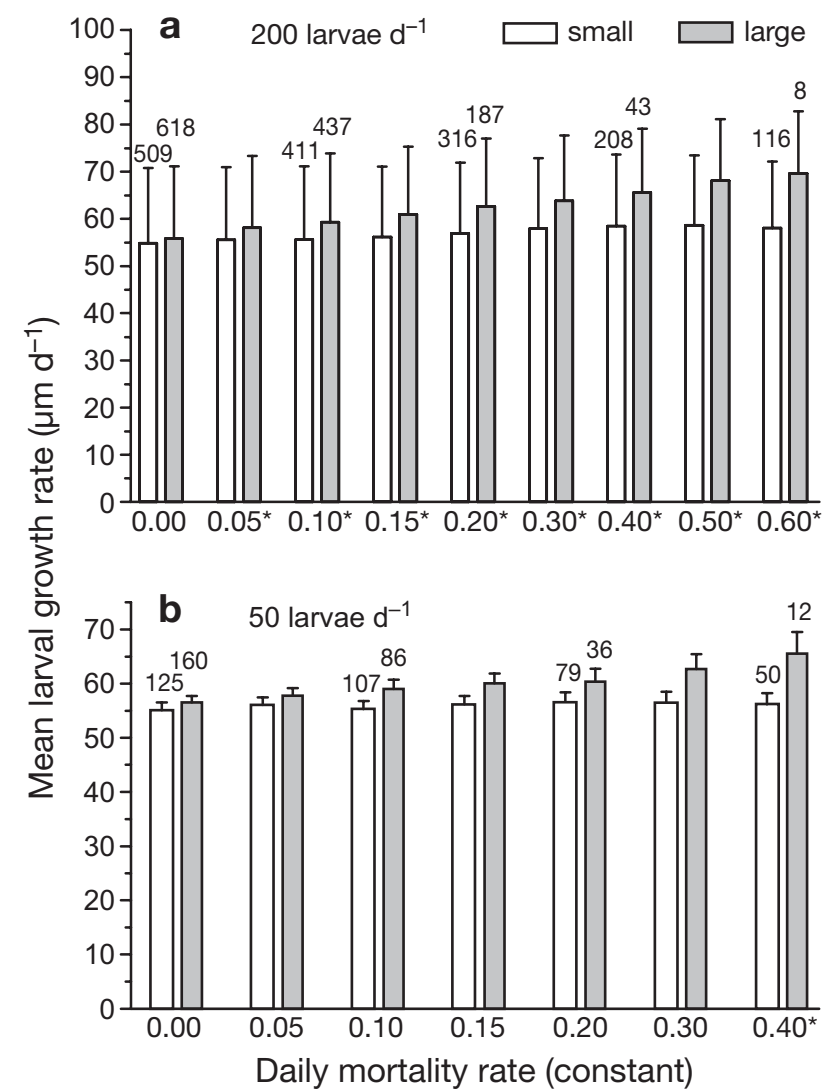

Fig. 8. Crepidula spp. Computer model. Influence of hatching rate and larval mortality rate on final growth rates of small (shell lengths $\leq 600 \mu \mathrm{m}$ ) and large (shell lengths $\geq 650 \mu \mathrm{m}$ ) larvae. Each bar represents mean $(+1 \mathrm{SD})$ growth rate of small or large larvae surviving at end of $30 \mathrm{~d}$; numbers above bars indicate number of surviving larvae. Each bar is mean of 10 runs of the simulation. ${ }^{*}$ Means differing significantly at $\mathrm{p}<0.05$

and therefore have been vulnerable to benthic predators, and should not have been disappearing from the plankton through metamorphosis. Since, although collected from the field, the larvae in this experiment were reared in the laboratory, and since larval growth rates for both species are constant in laboratory culture, the most likely explanation for these results is differential mortality of slower-growing individuals.

Alternatively, what we observed may have been size-specific responses of field-collected larvae to suboptimal conditions in the laboratory, caused, for example, by the greater energy stores of larger larvae. However, the fastest growth rates for large larvae were similar to those seen for small larvae, arguing against the hypothesis that larger larvae were physiologically healthier than smaller larvae. Also, when larvae of Crepidula fornicata are deprived of food in the laboratory, or even when they are merely subjected to greatly reduced food availability, there is no further detectable growth (Pechenik et al. 1996a,b): either the larvae of 


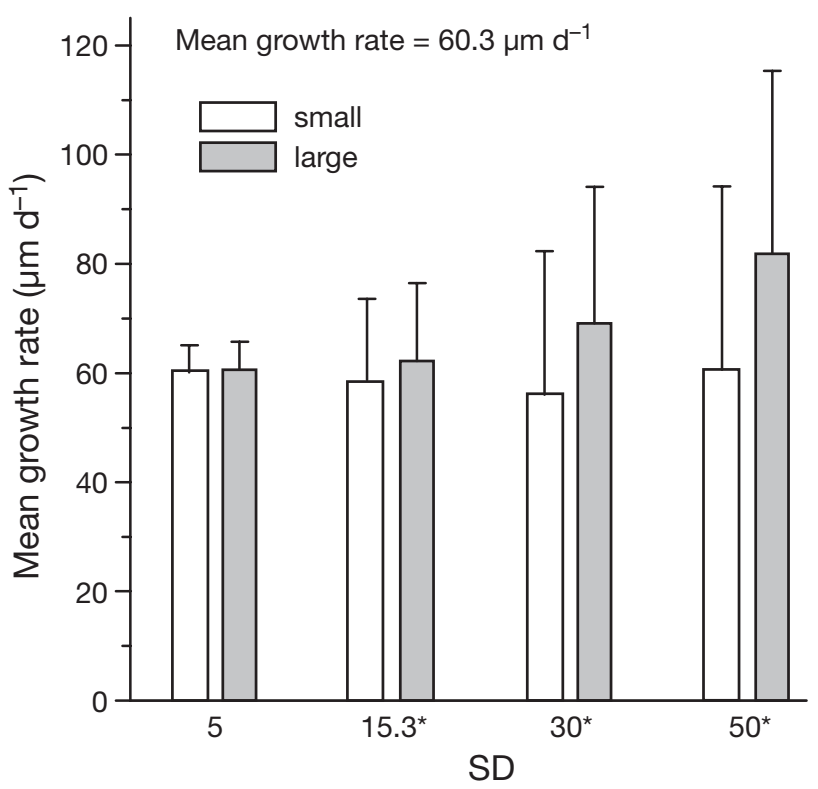

Fig. 9. Crepidula spp. Computer model. Influence of variation in larval growth rate on final growth rates of large and small larvae in computer simulation; 200 larvae hatching each day for $30 \mathrm{~d}$, daily mortality of $0.23 \mathrm{~d}^{-1}$, initial mean $( \pm \mathrm{SD})$ larval growth rate $=60.3 \pm 15 \mu \mathrm{m} \mathrm{d}^{-1}$. ${ }^{*}$ Means differing significantly at $\mathrm{p}<0.05$

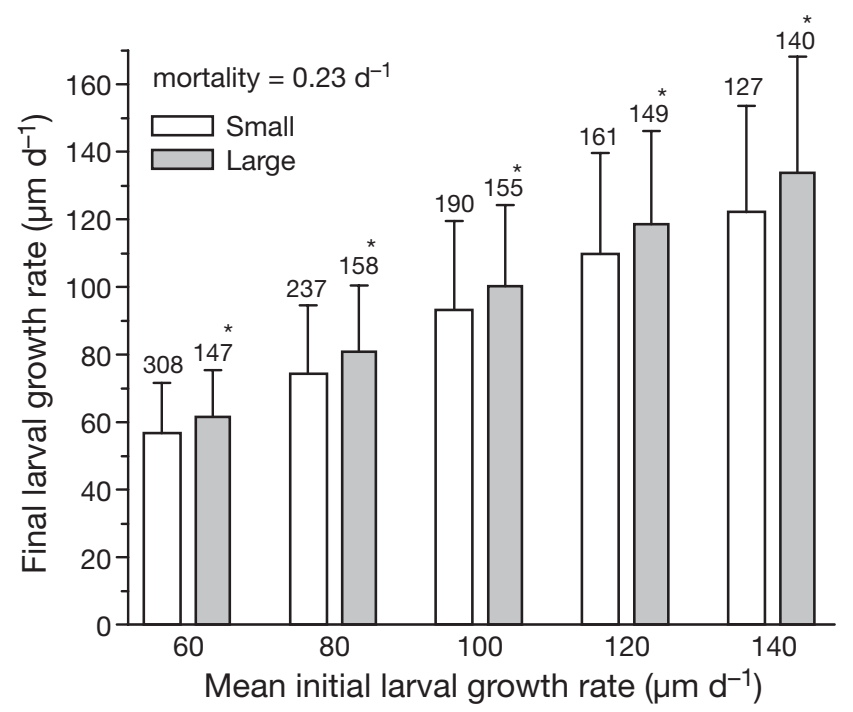

Fig. 10. Crepidula spp. Computer model. Influence of initial larval growth rate on mean $(+1 \mathrm{SD})$ final growth rates of large and small larvae in computer simulation; 200 larvae hatching each day for $30 \mathrm{~d}$, daily mortality of $0.23 \mathrm{~d}^{-1}$. SD was allowed to increase in proportion to each increase in mean initial larval growth rate (e.g. SD was 15 when initial larval growth rate was $60 \mu \mathrm{m} \mathrm{d}^{-1}$, but SD was 30 when initial growth rate was $120 \mu \mathrm{m} \mathrm{d}^{-1}$ ). ${ }^{*}$ Statistically significant difference between mean growth rates for large and small larvae $(p<0.05)$. Numbers above bars indicate number of survivors at end of the 30 d simulation this species do not carry energy stores, or such stores are diverted to maintenance rather than to growth under nutritionally challenging conditions. Finally, although Crepidula spp. in previous laboratory studies did not grow as quickly as they did when collected from the plankton in this study, they always typically grew at 50 to $100 \mu \mathrm{m} \mathrm{d}^{-1}$ with negligible mortality (e.g. Pechenik 1984, Pechenik \& Lima 1984), indicating that the conditions in previous laboratory studies were nevertheless quite good.

The computer simulations confirmed that such differences in the mean growth rates of large and small larvae can be expected for field populations under conditions of substantial larval mortality, even among mixed cohorts. To obtain size-specific mean growth rate differences of the magnitude seen in our field collections, our computer model (using a SD of mean growth rate of $15 \mu \mathrm{m} \mathrm{d}^{-1}$ ) requires planktonic mortality rates of about $50 \% \mathrm{~d}^{-1}$, about double the average mortality rate previously estimated for planktonic larvae (Strathmann 1985, Rumrill 1990, Morgan 1995, Lamare \& Barker 1999), but similar to estimates previously made for some individual species (reviewed by Rumrill 1990 \& Morgan 1995). As indicated by the computer simulation, if variation in larval growth rates in natural populations is greater than our modeled value of $15 \mu \mathrm{m}$, somewhat lower planktonic mortality rates would suffice to produce differences of such magnitude in mean larval growth rates. Monitoring how sizespecific larval growth rates for field-collected larvae reared in the laboratory change from week to week over an entire reproductive season might reveal weekly fluctuations in the magnitude of predation on larvae of these 2 species.

A somewhat similar approach to evaluating mortality was reported for fish larvae by Meekan \& Fortier (1996), with comparable results. Fish preserve a record of their growth rates in the banding patterns of their otoliths (Meekan \& Fortier 1996, Bergenius et al. 2002, Doherty et al. 2004, Takasuka et al. 2004a,b). Thus, past larval growth rates can be assessed from the otoliths of surviving juveniles and compared with those of existing larvae. For Atlantic cod Gadus morhua, those larvae that survived selection to reach the juvenile stage showed a narrower range of larval growth rates and a higher mean larval growth rate, suggesting that slower-growing larvae had borne a disproportionate share of deaths (Meekan \& Fortier 1996). In fact, Meekan \& Fortier (1996) estimated that during the winter of 1992 to 1993, faster-growing larvae were 3 times more likely to survive to the epibenthic stage than slower-growing larvae. More recently, Takasuka et al. (2004a,b) similarly inferred higher survival for faster-growing larval Japanese anchovy Engraulis japonicus, in part as a result of greater can- 
nibalism by anchovy juveniles on slow-growing than on fast-growing larvae (Takasuka et al. 2004b).

Estimates of planktonic mortality for invertebrate larvae range from $<3 \% \mathrm{~d}^{-1}$ (Johnson \& Shanks 2003, reviewed by Strathmann 1985, Rumrill 1990, Morgan 1995) to $80 \% \mathrm{~min}^{-1}$ (Olson \& McPherson 1987). Such very high mortality rates (recorded for ascidian larvae through observations by SCUBA) cannot possibly hold true for the larvae of longer-lived invertebrate species. With such mortality rates, even with a fecundity of 1 million offspring per spawning, all larvae would be killed within $15 \mathrm{~min}$, and selection would strongly favor eliminating larvae from the life cycles of most species (Pechenik 1999). Similarly, our results are not consistent with the very low mortality rates (essentially $0 \% \mathrm{~d}^{-1}$ ) that Johnson \& Shanks (2003) documented in field enclosures in the presence of normal background concentrations of plankton. As shown in our computer simulations, such low mortality rates cannot account for the size-specific differences in mean larval growth rates found in our study. The discrepancy with Johnson \& Shanks' (2003) data is intriguing, as their studies were large-scale, carefully planned, and carefully conducted. It may be that planktonic invertebrate larvae experience substantial mortality only sporadically, for example when large schools of planktivorous fish (Morgan \& Christy 1997) or cnidarian medusae (Cowan \& Houde 1993) move through a population.

Slow-growing larvae might be selected against for 2 reasons: (1) predation may be more intense on smaller larvae, so that slow-growing larvae remain in the more vulnerable size category for a longer time (reviewed by Rumrill 1990, Morgan 1995, Cowan et al. 1996, Takasuka et al. 2004a); or (2) slow-growing larvae will be susceptible to planktonic predation for a longer time than fast-growing larvae even when vulnerability to predators is not size-specific, simply because it generally takes longer for them to reach metamorphic competence (Pechenik 1984, Lima \& Pechenik 1985, Zimmerman \& Pechenik 1991). It is not yet clear how vulnerability to predators changes as invertebrate larvae grow (reviewed by Pechenik 1999); vulnerability might even increase with larger larval size for at least some prey and some predators (Pennington et al. 1986, Litvak \& Leggett 1992, Cowan \& Houde 1993, Pepin \& Shears 1995, Gleason \& Bengston 1996, reviewed by Pechenik 1999), reflecting either increased encounter rates between predators and prey, owing to faster swimming speeds (e.g. Fuiman 1989, 1994, Cowan et al. 1996, Letcher et al. 1996), or increased conspicuousness to visual predators (e.g. Fuiman 1989). Sizerelated vulnerability of larvae probably varies with predator species and predator size (reviewed by Pechenik 1999). Remarkably, our computer simulation produced significant differences in mean growth rates for large and small larvae whether predation rates increased, decreased, or remained constant with larval size (Fig. 5). In other words, if daily mortality rates are high in the plankton, it does not matter whether or not larvae are more or less vulnerable during part of the planktonic period-selection will still preferentially remove the slowest growing larvae as long as predation pressure is sufficiently substantial. Thus, the laboratory growth rate data from this study reveal nothing about the degree of size-selective predation on the larvae of these 2 species, only that the larvae were subject to intense predation for at least a substantial portion of their time in the plankton.

Our study is unusual in that it comprised a combination of field and laboratory approaches in which larvae were collected in the field, but then reared individually in the laboratory under controlled conditions of temperature and food supply. While it is common to transplant animals from the laboratory into the field (e.g. Moran \& Emlet 2001), or from one field site to another (e.g. Trussell 1996, Leonard et al. 1999), it is unusual for researchers to assess physiological condition of field-collected larvae by transplanting them from the field into the laboratory (but see Jarrett \& Pechenik 1997).

One surprising finding of the present study is the high mean growth rate of field-collected Crepidula fornicata larvae reared in the laboratory, consistently above $100 \mu \mathrm{m} \mathrm{d}^{-1}$. In previous studies with larvae of this species reared in the laboratory at 20 to $25^{\circ} \mathrm{C}$, growth rates have ranged from about 25 to $100 \mu \mathrm{m} \mathrm{d}^{-1}$ (e.g. Pechenik 1984, Pechenik et al. 1996a,c). In the present study, many larvae grew faster than $100 \mu \mathrm{m}$ $\mathrm{d}^{-1}$ in the laboratory on the same diet (Clone T-ISO), with some individuals growing as fast as 150 to $170 \mu \mathrm{m}$ $\mathrm{d}^{-1}$; indeed, mean growth rates for large larvae were as high as $130 \mu \mathrm{m} \mathrm{d}^{-1}$ (Fig. 2). The difference between this study and all previous studies with this species is that in prior studies larvae were released from parents and reared entirely in the laboratory, whereas in this study, larvae first spent time growing under natural conditions in the plankton. Our data suggest that larvae of this species are physiologically healthier in the field than in laboratory culture. It might be revealing to conduct similar studies on larval growth rates for other species.

Our laboratory data do not tell us how fast larvae actually grow in the field. In our study, larvae were reared in the laboratory at constant temperature and salinity, and with excess phytoplankton of a single species; in the field, larval growth rates will be affected by fluctuations in temperature, salinity, food concentration, food quality, and the possible presence of inhibitory chemicals from some phytoplankton (reviewed by Pechenik 1987). It would clearly be helpful to have 
reliable data on field growth rates, and on the extent of growth rate variation, for these species, although such data will prove difficult to obtain. In any event, our interpretation of results does not require larval growth rates of Crepidula fornicata or C. plana to be constant in the field, only that slower-growing larvae in the laboratory would also have been slower-growing larvae in the field. Although the larvae were collected from the field, they were reared in the laboratory under controlled conditions, so that growth rate differences for small and large larvae probably reflect underlying genetic differences rather than any physiological differences due to size differences per se. As noted earlier, broad sense heritability for larval growth in $C$. fornicata was estimated at 0.35 (Hilbish et al. 1999).

Finally, we suggest that the relationship between body size and growth rate needs further exploration in the larvae of more species. It is commonly assumed that larger larvae grow more quickly than smaller larvae of the same species, because larger larvae generally filter larger volumes of water per second and can probably ingest larger food particles (e.g. Strathmann 1987). However, both biomass and shell length increase linearly over time in laboratory culture for both Crepidula fornicata and C. plana at a variety of temperatures and food conditions (e.g. Pechenik 1978, 1980, 1984, Lima \& Pechenik 1985, Klinzing \& Pechenik 2000), and although shell growth rates decline with increasing size for larvae of the mudsnail Ilyanassa obsoleta (Scheltema 1967), biomass increases at a constant rate in larvae of that species (Pechenik 1980). Apparently, for at least the larvae of these 3 gastropod species, the increase in filtration rates that accompanies increased larval size is matched by corresponding increases in rates of energy expenditure (Pechenik 1980). More studies are needed to determine the relationships between size, filtration rate, metabolism, and growth to determine how exceptional these 3 species are.

Acknowledgements. We are grateful to 3 reviewers for their interesting and thought-provoking comments on the manuscript.

\section{LITERATURE CITED}

André C, Jonsson PR, Lindegarth M (1993) Predation on settling bivalve larvae by benthic suspension feeders: the role of hydrodynamics and larval behaviour. Mar Ecol Prog Ser 97:183-192

Atkinson OS, Yund PO (1996) The effect of variation in population density on male fertilization success in a colonial ascidian. J Exp Mar Biol Ecol 195:111-123

Bergenius MAJ, Meekan MG, Robertson DR, McCormick MI (2002) Larval growth predicts the recruitment success of a coral reef fish. Oecologia 131:521-525

Chowhury D, Nishinari K, Schadschneider A (2004) Self- organized patterns and traffic flow in colonies of organisms: from bacteria and social insects to vertebrates. Phase Transitions 77:601-624

Costello DP, Henley C (1971) Methods for obtaining and handling marine eggs and embryos, 2nd edn. Marine Biological Laboratory, Woods Hole, MA

Cowan JH Jr, Houde ED (1993) Relative predation potentials of scyphomedusae, ctenophores and planktivorous fish on ichthyoplankton in Chesapeake Bay. Mar Ecol Prog Ser 95:55-65

Cowan JH Jr, Houde ED, Rose KA (1996) Size-dependent vulnerability of marine fish larvae to predation: an individual-based numerical experiment. ICES J Mar Sci 53:23-37

Doherty PL, Dufour V, Galzin R, Hixon MA, Meekan MG, Planes S (2004) High mortality during settlement is a population bottleneck for a tropical surgeonfish. Ecology 85:2422-2428

Evans TP, Kelley H (2004) Multi-scale analysis of a household level agent-based model of landcover change. J Environ Manag 72:57-72

Fuiman LA (1989) Vulnerability of Atlantic herring larvae to predation by yearling herring. Mar Ecol Prog Ser 51: 291-299

Fuiman LA (1994) The interplay of ontogeny and scaling in the interactions of fish larvae and their predators. J Fish Biol 45(Suppl A):55-79

Gleason TR, Bengston DA (1996) Growth, survival and sizeselective predation mortality of larval and juvenile inland silversides, Menidia beryllina (Pisces; Atherinidae). J Exp Mar Biol Ecol 199:165-177

Gosselin LA, Qian PY (1997) Juvenile mortality in benthic marine invertebrates. Mar Ecol Prog Ser 146:265-282

Hilbish TJ, Sasada K, Eyster LS, Pechenik JA (1999) Relationship between rates of swimming and growth in veliger larvae: genetic variance and covariance. J Exp Mar Biol Ecol 239:183-193

Hines AH (1986) Larval problems and perspectives in life histories of marine invertebrates. Bull Mar Sci 39:506-525

Hunt HL, Scheibling RE (1997) Role of early post-settlement mortality in recruitment of benthic marine invertebrates. Mar Ecol Prog Ser 155:269-301

Jarrett JN, Pechenik JA (1997) Temporal variation in cyprid quality and juvenile growth capacity for an intertidal barnacle. Ecology 78:1262-1265

Johnson KB, Shanks AL (2003) Low rates of predation on planktonic marine invertebrate larvae. Mar Ecol Prog Ser 248:125-139

Klinzing MSE, Pechenik JA (2000) Evaluating whether velar lobe size indicates food limitation among larvae of the marine gastropod Crepidula fornicata. J Exp Mar Biol Ecol 252:255-279

Lamare M, Barker M (1999) In situ estimates of larval development and mortality in the New Zealand sea urchin Evechinus chloroticus (Echinodermata: Echinoidea). Mar Ecol Prog Ser 180:197-211

Leonard GH, Bertness MD, Yund PO (1999) Crab predation, waterborne cues, and inducible defenses in the blue mussel, Mytilus edulis. Ecology 80:1-14

Letcher BH, Rice JA, Crowder LB, Rose KA (1996) Variability in survival of larval fish: disentangling components with a generalized individual-based model. Can J Fish Aquat Sci 53:787-801

Levene H (1960) Essays in honor of Harold Hotelling. In: Olkin I, Ghurye SG, Hoeffding W, Madow WG, Mann HB (eds) Contributions to probability and statistics. Stanford University Press, Palo Alto, CA, p 278-292

Levitan DR, Sewell MA, Chia FS (1992) How distribution and 
abundance influence fertilization success in the sea urchin Strongylocentrotus franciscanus. Ecology 73:248-254

Lima G, Pechenik JA (1985) The influence of temperature on growth rate and length of larval life of the gastropod Crepidula plana Say. J Exp Mar Biol Ecol 90:55-71

Litvak MK, Leggett WC (1992) Age and size-selective predation on larval fishes: the bigger-is-better hypothesis revisited. Mar Ecol Prog Ser 81:13-24

Marshall DJ (2002) In situ measures of spawning synchrony and fertilization success in an intertidal, free-spawning invertebrate. Mar Ecol Prog Ser 236:113-119

Meekan MG, Fortier L (1996) Selection for fast growth during the larval life of Atlantic cod Gadus morhua on the Scotian Shelf. Mar Ecol Prog Ser 137:25-37

Moran AL, Emlet RB (2001) Offspring size and performance in variable environments: field studies on a marine snail. Ecology 82:1597-1612

Morgan SG (1995) Life and death in the plankton: larval mortality and adaptation. In: McEdward L (ed) Ecology of marine invertebrate larvae. CRC Press, Boca Raton, FL, p 279-321

Morgan SG, Christy JH (1997) Planktivorous fishes as selective agents for reproductive synchrony. J Exp Mar Biol Ecol 209:89-101

Namatame A, Terano T, Kurumatani K (2002) Agent-based approaches in economic and social complex systems. Front Artif Intell Appl 72:1-192

Olson RR, McPherson R (1987) Potential vs. realized larval dispersal: fish predation on larvae of the ascidian Lissoclinum patella (Gottschaldt). J Exp Mar Biol Ecol 110: 245-256

Pechenik JA (1978) Growth and energy balance during the development and delay of metamorphosis of larval gastropods. PhD thesis, University of Rhode Island, Kingston, RI

Pechenik JA (1979) Role of encapsulation in invertebrate life histories. Am Nat 114:859-870

Pechenik JA (1980) Growth and energy balance during the larval lives of three prosobranch gastropods. J Exp Mar Biol Ecol 44:1-28

Pechenik JA (1984) The relationship between temperature, growth rate, and duration of planktonic life for larvae of the gastropod Crepidula fornicata (L.). J Exp Mar Biol Ecol 74:241-257

Pechenik JA (1986) Field evidence for delayed metamorphosis of larval gastropods: Crepidula plana Say, Crepidula fornicata (L.), and Bittium alternatum (Say). J Exp Mar Biol Ecol 97:313-319

Pechenik JA (1987) Environmental influences of larval survival and development. In: Giese AC, Pearse JS, Pearse VB (eds) Reproduction of marine invertebrates, Vol IX. Blackwell, Los Angeles, CA, p 551-608

Pechenik JA (1999) On the advantages and disadvantages of larval stages in benthic marine invertebrate life cycles. Mar Ecol Prog Ser 177:269-297

Pechenik JA, Gee CC (1993) Onset of metamorphic competence in larvae of the gastropod Crepidula fornicata (L.), judged by a natural and an artificial cue. J Exp Mar Biol Ecol 167:59-72

Pechenik JA, Heyman WD (1987) Using $\mathrm{KCl}$ to determine size at competence for larvae of the marine gastropod Crepidula fornicata (L.). J Exp Mar Biol Ecol 112:27-38

Pechenik JA, Lima G (1984) Relationship between growth, differentiation, and length of larval life for individually reared larvae of the marine gastropod, Crepidula fornicata. Biol Bull (Woods Hole) 166:537-549

Pechenik JA, Estrella MS, Hammer K (1996a) Food limitation stimulates metamorphosis of competent larvae and alters postmetamorphic growth rate in the marine prosobranch gastropod Crepidula fornicata. Mar Biol 127:267-275

Pechenik JA, Hammer K, Weise C (1996b) The effect of starvation on acquisition of competence and post-metamorphic performance in the marine prosobranch gastropod Crepidula fornicata (L.). J Exp Mar Biol Ecol 199:137-152

Pechenik JA, Hilbish TJ, Eyster LS, Marshall D (1996c) Relationship between larval and juvenile growth rates in two marine gastropods, Crepidula plana and C. fornicata. Mar Biol 125:119-127

Pechenik JA, Li W, Cochrane DE (2002) Timing is everything: the effects of putative dopamine antagonists on metamorphosis vary with larval age and experimental duration in the prosobranch gastropod Crepidula fornicata. Biol Bull (Woods Hole) 202:137-147

Pechenik JA, Blanchard M, Rotjan R (2004) Susceptibility of larval Crepidula fornicata to predation by suspensionfeeding adults. J Exp Mar Biol Ecol 306:75-94

Pennington JT (1985) The ecology of fertilization of echinoid eggs - the consequences of sperm dilution, adult aggregation, and synchronous spawning. Biol Bull (Woods Hole) 169:417-430

Pennington JT, Rumrill SS, Chia FS (1986) Stage-specific predation upon embryos and larvae of the Pacific sand dollar, Dendraster excentricus, by 11 species of common zooplankton predators. Bull Mar Sci 39:234-240

Pepin P, Shears TH (1995) Influence of body size and alternate prey abundance on the risk of predation to fish larvae. Mar Ecol Prog Ser 128:279-285

Pie MR, Rosengaus RB, Traniello JFA (2004) Nest architecture, activity pattern, worker density and the dynamics of disease transmission in social insects. J Theor Biol 226: $45-51$

Rumrill SS (1990) Natural mortality of marine invertebrate larvae. Ophelia 32:163-198

Scheltema RS (1967) The relationship of temperature to the larval development of Nassarius obsoletus (Gastropoda). Biol Bull (Woods Hole) 132:253-265

Stoner DS (1990) Recruitment of a tropical colonial ascidian: relative importance of pre-settlement vs. post-settlement processes. Ecology 71:1682-1690

Strathmann RR (1985) Feeding and nonfeeding larval development and life-history evolution in marine invertebrates. Annu Rev Ecol Syst 16:339-361

Strathmann RR (1987) Larval feeding. In: Giese AC, Pearse JS, Pearse VB (eds) Reproduction of marine invertebrates, Vol IX. General aspects: seeking unity in diversity. Blackwell Scientific, Palo Alto, CA, p 487-489

Takasuka A, Aoki I, Mitani I (2004a) Three synergistic growthrelated mechanisms in the short-term survival of larval Japanese anchovy Engraulis japonicus in Sagami Bay. Mar Ecol Prog Ser 270:217-228

Takasuka A, Oozeki Y, Kimura R, Kubota H, Aoki I (2004b) Growth-selective predation hypothesis revisited for larval anchovy in offshore waters: cannibalism by juveniles versus predation by skipjack tunas. Mar Ecol Prog Ser 278: 297-302

Thiriot-Quivreux C, Scheltema RS (1982) Planktonic larvae of New England gastropods. V. Bittium alternatum, Triphora nigrocincta Cerithiopsis emersoni, Lunatia heros and Crepidula plana. Malacologia 23:37-46

Thorson G (1950) Reproductive and larval ecology of marine bottom invertebrates. Biol Rev 25:1-45

Thorson G (1966) Some factors influencing the recruitment and establishment of marine benthic communities. Neth J Sea Res 3:267-293 
Trussell GC (1996) Phenotypic plasticity in an intertidal snail: the role of a common crab predator. Evolution 50:448-454

Walters LJ, Wethey DS (1996) Settlement and early postsettlement survival of sessile marine invertebrates on topographically complex surfaces: the importance of refuge dimensions and adult morphology. Mar Ecol Prog Ser 137: 161-171

Young CM, Chia FS (1987) Abundance and distribution of pelagic larvae as influenced by predation, behavior, and hydrographic factors. In: Giese AC, Pearse JS, Pearse VB

Editorial responsibility: Lisa Levin (Contributing Editor), La Jolla, California, USA (eds) Reproduction of marine invertebrates, Vol IX. Blackwell Scientific, Palo Alto, CA, p 385-463

Yund PO, McCartney MA (1994) Male reproductive success in sessile invertebrates: competition for fertilizations. Ecol Monogr 75:2151-2167

Zimmerman KM, Pechenik JA (1991) How do temperature and salinity affect relative rates of growth, morphological differentiation, and time to metamorphic competence in larvae of the marine gastropod Crepidula plana? Biol Bull (Woods Hole) 180:372-386

Submitted: October 22, 2004; Accepted: Januuary 24, 2007 Proofs received from author(s): August 6, 2007 